\title{
NMR Study of the Degradation Products of Ethylene Carbonate in Silicon - Lithium Ion Batteries
}

\author{
Yanting Jin, ${ }^{\dagger}$ Nis-Julian H. Kneusels, ${ }^{+}$Clare P. Grey ${ }^{*}{ }^{\dagger}$ \\ ${ }^{\dagger}$ Department of Chemistry, University of Cambridge, Lensfield \\ Road, Cambridge CB2 1EW, United Kingdom
}

\section{Content:}

1. Experimental

2. Electrochemical data

3. Solution NMR

4. ${ }^{1} \mathrm{H}$ and ${ }^{13} \mathrm{C}$ chemical shifts of oligomers calculated by ChemDraw

5. Mass spectrometry data

6. Simulated NMR spectra of oligomers and ${ }^{1} \mathrm{H}$ integral

\section{Experimental}

Coin cells: silicon nanowires (SiNWs)-Li half cells were prepared using LP30 or LP30 $+{ }^{13} \mathrm{C}_{3} \mathrm{EC}(1 \mathrm{M}$ LiPF 6 in $\left.E C /{ }^{13} C_{3} E C / D M C=1 / 1 / 2, v / v / v\right)$ electrolyte. Cells were cycled at $C / 30(120 \mathrm{~mA} / \mathrm{g})$ between $0-2 \mathrm{~V}$ for $30-50$ cycles. Details about the materials, synthesis of SiNWs and coin cell preparation can be found in reference ${ }^{1}$.

Solution NMR: after cycling, cells were disassembled, and the separator was soaked in $\sim 0.6 \mathrm{ml} \mathrm{d}_{6}$-DMSO, then the solution was transferred into an air-tight J-Y NMR tube for solution NMR measurement. Spectra were recorded on a $500 \mathrm{MHz}$ Bruker Avance III HD, with a DCH (carbon observe) cryoprobe or Bruker AVANCE 400 equipped with a BBO probe. Spectra are internal referenced to $d_{5}$-DMSO $\left({ }^{1} \mathrm{H}\right.$ at $2.50 \mathrm{ppm}$ and ${ }^{13} \mathrm{C}$ at $\left.39.53 \mathrm{ppm}\right)$. The ${ }^{13} \mathrm{C}-$ ${ }^{13} \mathrm{C}$ COSY spectrum was recorded using a Bruker COSY-DQF pulse program: F2 $\left({ }^{13} \mathrm{C}\right)$ was acquired using a time domain of 4096 points, F1 $\left({ }^{13} \mathrm{C}\right) 1024$ increments, over 236 ppm. The relaxation delay was $3 \mathrm{~s}$ and 40 scans per slice were used.

The ${ }^{1} \mathrm{H}$ Diffusion Spectroscopy (DOSY) experiment was performed using a Bruker pulse program 'ledbpgp2s' with bipolar gradient pulse for diffusion. ${ }^{2} 32$ spectra with varying gradient strengths have been recorded with a diffusion 
delay of $10 \mathrm{~ms}$ and the gradient pulse width of $2 \mathrm{~ms}$. Linear fitting of the intensity decay versus the gradient using Dynamic Center (Bruker) software provides the diffusion coefficients for each species.

Electrospray-ionization High Resolution Mass Spectrometry (ESI-HRMS): Cycled SiNWs were soaked in acetonitrile for $48 \mathrm{~h}$ to dissolve the organic SEI. SiNWs were removed by centrifuge and the supernatant was diluted by a factor of 3 for three times using $\mathrm{CH}_{3} \mathrm{CN}$ before the measurements. All procedures were performed in air. ESI-HRMS experiments were performed in the positive ion mode on a Q-TOF instrument (Waters Xevo G2-S) equipped with a pneumatically assisted electrospray ion source (Z-spray) and an additional sprayer for the reference compound (LockSpray). The prepared solutions were directly introduced via an integrated syringe pump (5-10 L min-1) in the electrospray source. The source and desolvation temperatures were kept at 80 and $150{ }^{\circ} \mathrm{C}$, respectively. Nitrogen was used as a drying and nebulizing gas at flow rates of 350 and $50 \mathrm{~L} \mathrm{~h}^{-1}$, respectively. The capillary voltage was $2.5 \mathrm{kV}$, the cone voltage $100 \mathrm{~V}$, and the rf lens 1 energy $60 \mathrm{~V}$. Calibration of the instrument was performed using the ions produced by a phosphoric acid solution $\left(0.2 \%\right.$ in $\left.\mathrm{H}_{2} \mathrm{O} / \mathrm{CH}_{3} \mathrm{CN}, 50 / 50 \mathrm{v} / \mathrm{v}\right)$. The mass range was 50-1000 Da and spectra were recorded at $1 \mathrm{~s} \mathrm{scan}^{-1}$ in the profile mode at a resolution of 10,000 full width at half-maximum (FWMH). Data acquisition and processing were performed using MassLynx $\vee 4.0$ software.

Calculations of ${ }^{1} \mathrm{H}$ and ${ }^{13} \mathrm{C}$ chemical shift were obtained from ChemDraw Software (professional 16.0) via empirical method.

\section{Electrochemical data}

(a)

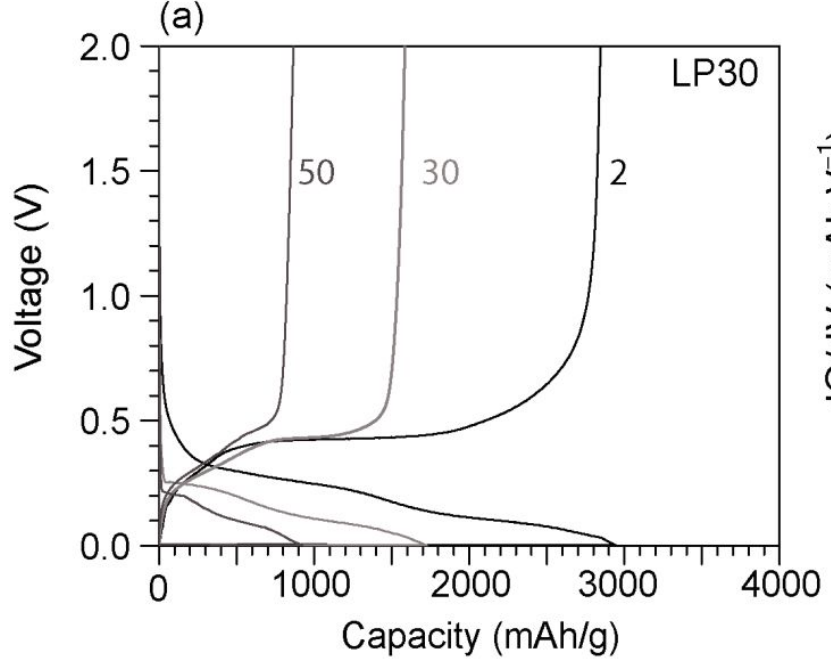

(b)

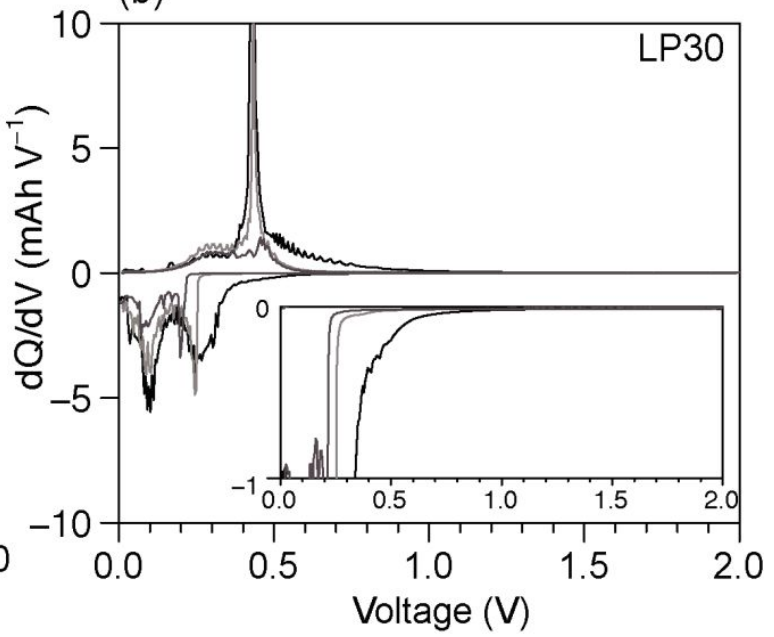

Figure S1 Discharge/charge curves and the $d Q / d V$ plot of a Si-Li half-cell cycled in LP30 based electrolyte. 


\section{Solution NMR data}

\subsection{Hydrolysis of lithium methyl carbonate to form methanol}

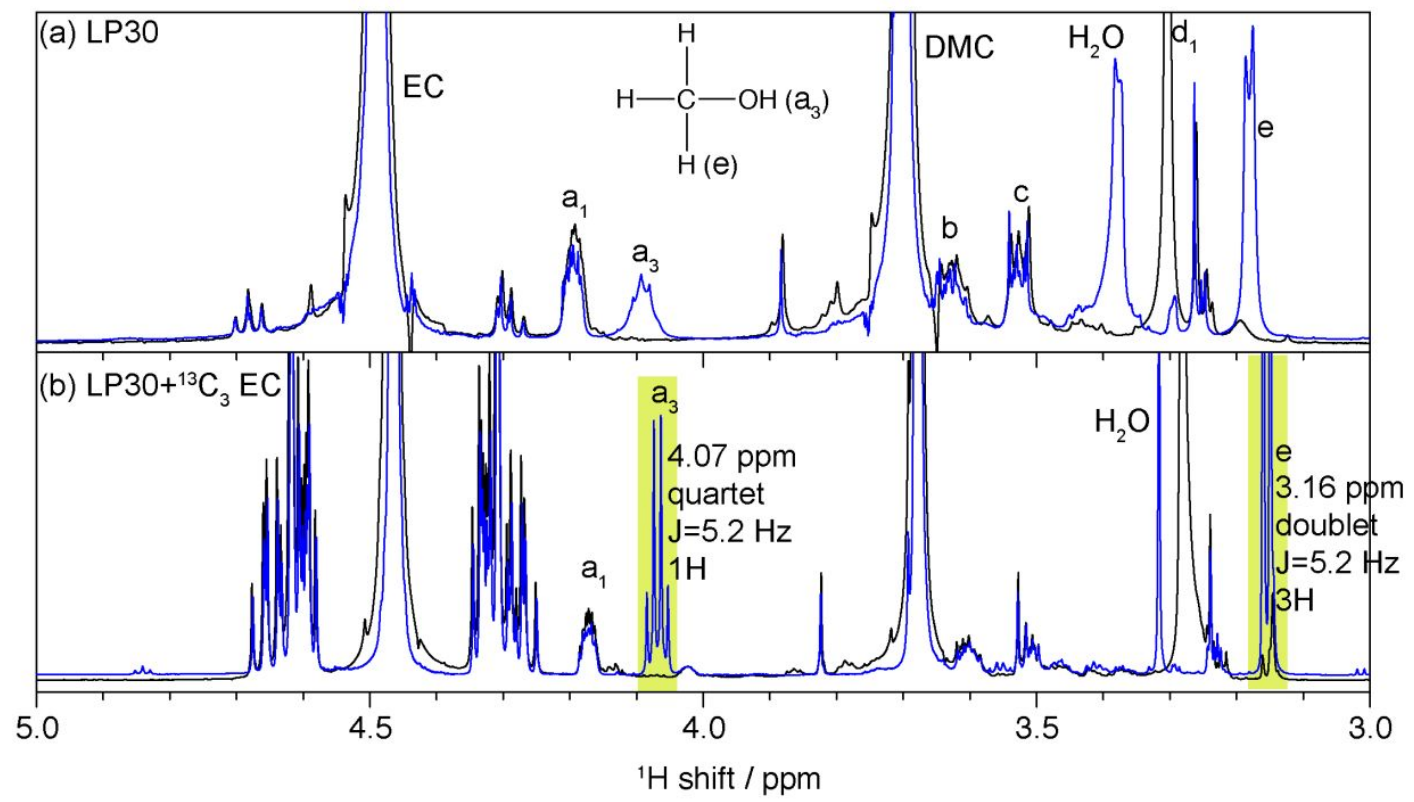

Figure S2. ${ }^{1} \mathrm{H}$ solution NMR of cycled $L P 30$ and $L P 30+{ }^{13} C_{3} E C$ electrolytes. The black spectrum is the electrolyte measured immediately after cell disassembly, while the blue spectrum is acquired on the same sample but after water contamination. After moisture permeates into the NMR tube, the $d_{1}$ peak at $3.30 \mathrm{ppm}$ corresponding to lithium methyl carbonate $\left(\mathrm{LMC}, \mathrm{LiOCOOCH}_{3}\right)$ decreases with the concomitant emergence of new peaks labelled as $\mathrm{a}_{3}$ and e that corresponds to methanol.

For the ${ }^{13} \mathrm{C}_{3} \mathrm{EC}$ sample, the $\mathrm{a}_{3}$ peak at $4.07 \mathrm{ppm}$ is clearly a quartet with $\mathrm{J}=5.2 \mathrm{~Hz}$, and the proton peak e at 3.16 ppm is a doublet with $\mathrm{J}=5.2 \mathrm{~Hz}$. The peak integral ratio between $\mathbf{a}_{3}$ and $\mathbf{e}$ is $1: 3$. Moreover, protons $\mathbf{a}_{3}$ and $\mathbf{e}$ are linked to each other in the ${ }^{1} \mathrm{H}$ COSY spectrum (Figure 2a). Combing all the information, $\underline{a}_{3} \underline{-e}$ is unambiguously assigned to methanol. It is worth noting that methanol shows two singlets in $\mathrm{CDCl}_{3}$ solvent, but it shows a welldefined J-coupling pattern when measured in DMSO solvent, probably due to the high viscosity of the DMSO solvent that slows down the molecular motion. The complete conversion from LMC to methanol also indicates that LMC is highly water sensitive.

\subsection{Analysis of the $d_{2}$ proton}

While the same one-bond and multi-bond correlations are identified for protons at $\mathbf{a}_{1}, \mathbf{b}$ and $\mathbf{c}$ in the ${ }^{1} \mathrm{H}$ NMR for both ${ }^{13} \mathrm{C}$-labelled and non-labelled samples, differences are observed for the protons in the $\mathbf{d}$ region (3.24-3.28 ppm). For the non-labelled LP30 sample, the proton at $\mathbf{d}_{\mathbf{2}}(3.26 \mathrm{ppm})$ is connected to a carbon with a ${ }^{13} \mathrm{C}$ shift at $58.5 \mathrm{ppm}$ in the HSQC spectrum (Figure $2 \mathrm{~b}$ ). Based on the one-bond correlation, $\mathbf{d}_{\mathbf{2}}$ is assigned to a methoxide group $\left(\mathrm{ROC} \underline{H}_{3}\right)$. Such correlation is, however, not visible in the ${ }^{13} \mathrm{C}$-labelled sample (Figure $2 \mathrm{e}$ ) as its intensity is below the contour level shown here. The fact that the correlation intensity for $\mathbf{d}_{2}$ protons in the ${ }^{13} C_{3} E C$ sample is weak indicates that the methoxide group may not come from ${ }^{13} \mathrm{C}_{3} \mathrm{EC}$ but $\mathrm{DMC}$, which contains mainly ${ }^{12} \mathrm{C}$ isotope (i.e. $\mathrm{RO}^{12} \mathrm{CH}_{3}$ ). Interestingly, multi-bond correlation is observed for protons at $\mathbf{d}_{\mathbf{2}}$ and an ethylene oxide carbon with ${ }^{13} \mathrm{C}$ resonance at $70 \mathrm{ppm}$ for the $\mathrm{LP} 30+{ }^{13} \mathrm{C}_{3} \mathrm{EC}$ sample (Figure $2 \mathrm{f}$ ). This correlation peak has similar intensity as those peaks containing protons at $\mathbf{a}_{\mathbf{1}}, \mathbf{b}$ and $\mathbf{c}$. Normally, correlation peak intensities are weaker in HMBC spectra than those observed in the HSQC spectrum. The appearance of correlation for $\mathbf{d}_{\mathbf{2}}$ in the HMBC but not in HSQC spectrum suggests that the proton at $\mathbf{d}_{\mathbf{2}}$ is further bound to a ${ }^{13} \mathrm{C}$ isotope, probably formed from ${ }^{13} \mathrm{C}_{3} \mathrm{EC}$. We now 
assign the $d_{2}$ peak to a motif with the structure of $\mathrm{R}^{13} \mathrm{CH}_{2} \mathrm{O}^{12} \underline{H}_{3}$, and it may be the product formed due to a reaction between $\mathrm{DMC}$ and ${ }^{3} \mathrm{C}_{3}-\mathrm{EC}$.

The terminal methoxide group is identified by a clear correlation between the proton $\mathbf{d}_{\mathbf{2}}$ and a carbon with resonance at $70 \mathrm{ppm}$, which is the carbon $\mathbf{C}$ in the labelling scheme in the HMBC spectra (Figure 2c and $\mathrm{f}$ ); this confirms that proton $\mathbf{d}_{\mathbf{2}}$ is connected to the $\underline{\mathbf{a}}_{1}-\underline{b-\mathbf{b}}$ oligomer. However, the diffusion coefficient for proton $\mathbf{d}_{\mathbf{2}}$ is slightly higher than proton $\mathbf{c}$ as shown in the DOSY NMR spectrum (4.94E-10 m/s $/ \mathrm{s}^{2}$ for $\mathbf{d}_{\mathbf{2}}$ and $4.41 \mathrm{E}-10 \mathrm{~m} / \mathrm{s}^{2}$ for $\left.\mathbf{c}\right)$. This small difference may arise from the systematic error in the DOSY experiment. Because proton $\mathbf{a}_{3}$ and e exhibits different diffusion coefficients at $7.46 \mathrm{E}-10$ and $8.04 \mathrm{E}-10 \mathrm{~m} / \mathrm{s}^{2}$, respectively, while they have been clearly identified to be protons in the methanol molecule. Therefore, it is believed that proton $d_{2}$ is most likely to be the end group for the $\underline{\mathbf{a}_{1}} \underline{-\mathbf{b}-\mathbf{c}}$ oligomer instead of being a part of another oligomer.

\subsection{Summary of 2D NMR correlation data in Figure 2.}

Table S1. Assignments of the 2D correlation NMR in Error! Reference source not found.. Correlations value marked with * are not shown in the figure but are present in a lower contour level.

\begin{tabular}{|c|c|c|c|c|c|c|c|}
\hline \multirow{3}{*}{ Electrolyte } & \multirow{3}{*}{ Index } & \multicolumn{5}{|c|}{ Shift/ppm } & \multirow[t]{3}{*}{ Possible assignments } \\
\hline & & \multicolumn{2}{|c|}{ HSQC } & \multirow{2}{*}{$\begin{array}{l}\text { HMBC } \\
{ }^{13} \mathrm{C}\end{array}$} & \multicolumn{2}{|c|}{${ }^{1} \mathrm{H}-{ }^{1} \mathrm{H}$ COSY } & \\
\hline & & ${ }^{1} \mathrm{H}$ & ${ }^{13} \mathrm{C}$ & & ${ }^{1} \mathrm{H}$ & $\begin{array}{c}{ }^{1} \mathrm{H} \\
\text { index }\end{array}$ & \\
\hline \multirow{6}{*}{ LP30 } & $a_{1}$ & 4.20 & 67.4 & $155.5 / 68.6$ & $3.6 / 3.5$ & $\mathrm{~b} / \mathrm{c}$ & $\begin{array}{c}\underline{a_{1}-\underline{b} / \mathbf{c}} \\
\text { ROCOO- } \underline{\underline{\mathbf{C H}}}{ }_{2} \mathrm{CH}_{2} \mathrm{OR}^{\prime}\end{array}$ \\
\hline & $a_{3}$ & 4.10 & - & 49.1 & 3.18 & e & $\mathrm{CH}_{3} \mathrm{OH}$ \\
\hline & $\mathrm{b}$ & 3.63 & 68.6 & $68.6 / 70.1$ & 4.20 & $a_{1}$ & $\mathrm{ROCOO}-\mathrm{CH}_{2} \mathrm{CH}_{2} \mathrm{OCH}_{2} \mathrm{R}^{\prime}$ \\
\hline & c & 3.52 & 70.0 & $68.6 / 70.1$ & 4.20 & $a_{1}$ & $\mathrm{ROCOO}-\mathrm{CH}_{2} \underline{\mathrm{CH}}_{2} \mathrm{OCH}_{2} \mathrm{R}^{\prime}$ \\
\hline & $\mathrm{d}_{2}$ & 3.26 & 58.5 & 70.0 & & & $\mathrm{RCH}_{2} \mathrm{OCH}_{3}$ \\
\hline & $\mathrm{e}$ & 3.18 & 49.1 & & 4.10 & $a_{3}$ & $\underline{\mathrm{CH}_{3} \mathrm{OH}}$ \\
\hline \multirow{5}{*}{$\begin{array}{l}\text { LP30+ } \\
{ }^{13} \mathrm{C}_{3} \mathrm{EC}\end{array}$} & $a_{1}$ & 4.17 & 67.1 & 156.9 & $3.6 / 3.5$ & $\mathrm{~b} / \mathrm{c}$ & $\mathrm{ROCOO} \underline{C H}_{2} \mathrm{CH}_{2} \mathrm{OR}^{\prime}$ \\
\hline & $\mathrm{b}$ & 3.60 & 68.6 & $68.6 / 70.1$ & 4.17 & $a_{1}$ & $\mathrm{ROCOOCH}_{2} \underline{\mathrm{CH}}_{2} \mathrm{OR}^{\prime}$ \\
\hline & $\mathrm{C}$ & 3.51 & 70.1 & 68.6 & 4.17 & $a_{1}$ & $\mathrm{ROCOOCH}_{2} \underline{\mathrm{CH}}_{2} \mathrm{OR}^{\prime}$ \\
\hline & $d_{1}$ & 3.28 & 51.8 & 158.7 & 1.15 & & ${\underline{\mathrm{CH}_{3}}}_{\text {methyl carbonate) }}$ \\
\hline & $d_{2}$ & 3.24 & $58.4^{*}$ & 70.1 & & & $\mathrm{RCH}_{2} \mathrm{OCH}_{3}$ \\
\hline
\end{tabular}



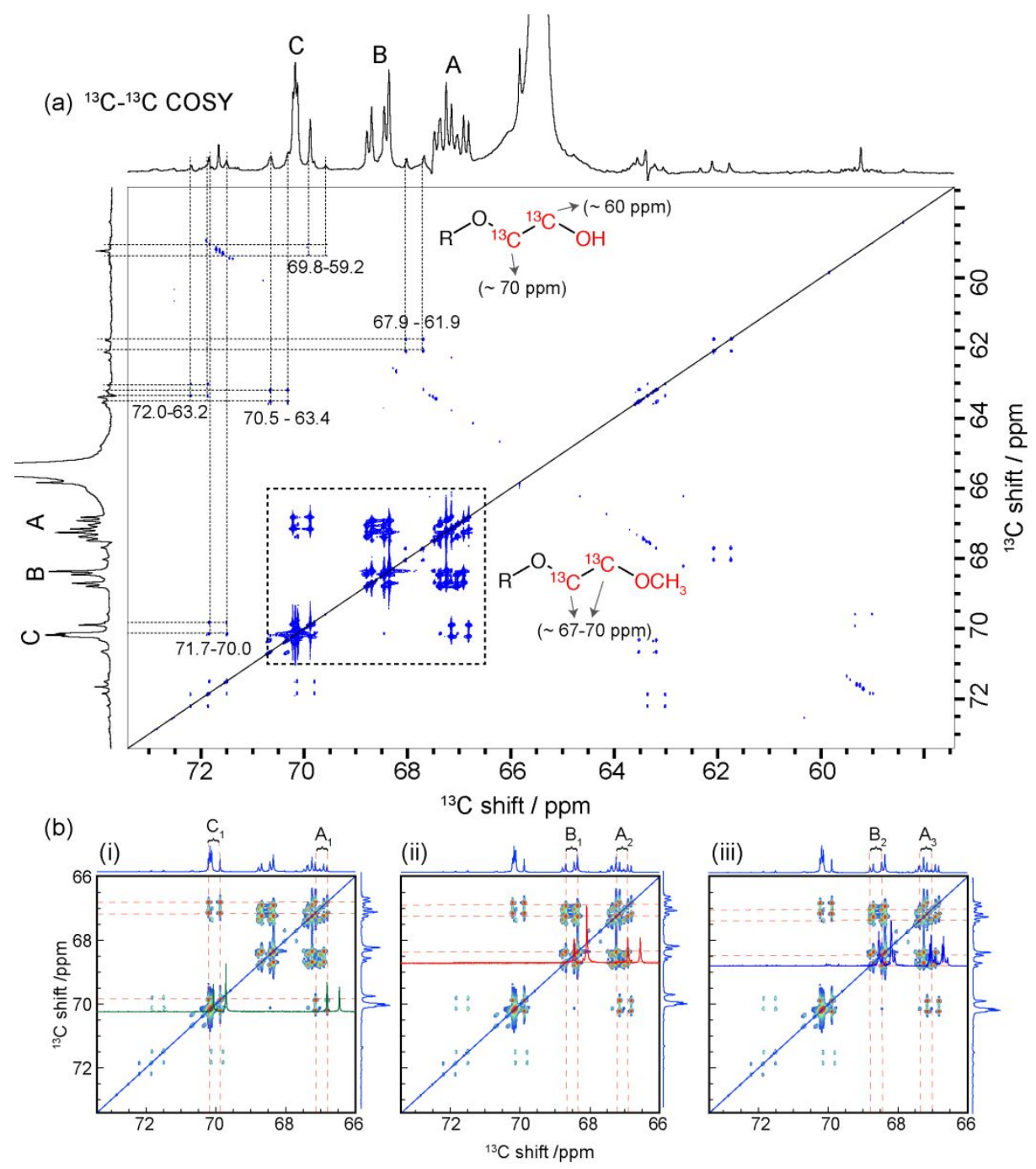

Figure S3. (a) Full ${ }^{13} \mathrm{C}-{ }^{13} \mathrm{C}$ COSY spectrum of cycled $L P 30+{ }^{13} C_{3} E C$. The central diagonal peak of ${ }^{13} C_{3} E C$ is removed for spectrum clarity. (b) zoomed in part of the $A-B-C$ part. The $1 D$ slices extracted from the ${ }^{13} \mathrm{C} C O S Y$ cross peaks are displayed.

An off-diagonal peak in the ${ }^{13} \mathrm{C}$ COSY NMR spectrum indicates a direct bond between the two carbons. Strong correlation peaks between carbons $\mathbf{A}, \mathbf{B}$ and $\mathbf{C}$ in the region of 67-70 ppm are observed and these peaks can be assigned to ethylene oxide (EO) units with methoxide end groups. Weak cross-peaks for carbons at $\sim 70 \mathrm{ppm}$ and $\sim 60 \mathrm{ppm}$ regions are also present and are assigned to EO units with hydroxyl terminals based on their chemical shifts. The epoxy carbon bound to a methoxide $\left(\mathrm{R}_{\underline{C}} \mathrm{H}_{2} \mathrm{OCH}_{3}\right)$ has a ${ }^{13} \mathrm{C}$ shift around $70 \mathrm{ppm}$, while the carbon bound to a hydroxyl end group $\left(\mathrm{R} \underline{\mathrm{C}} \mathrm{H}_{2} \mathrm{OH}\right)$ should have a lower ${ }^{13} \mathrm{C}$ shift at about $60 \mathrm{ppm}$ based on empirical calculations. 
4. $\quad{ }^{1} \mathrm{H}$ and ${ }^{13} \mathrm{C}$ chemical shifts of oligomers calculated by ChemDraw.

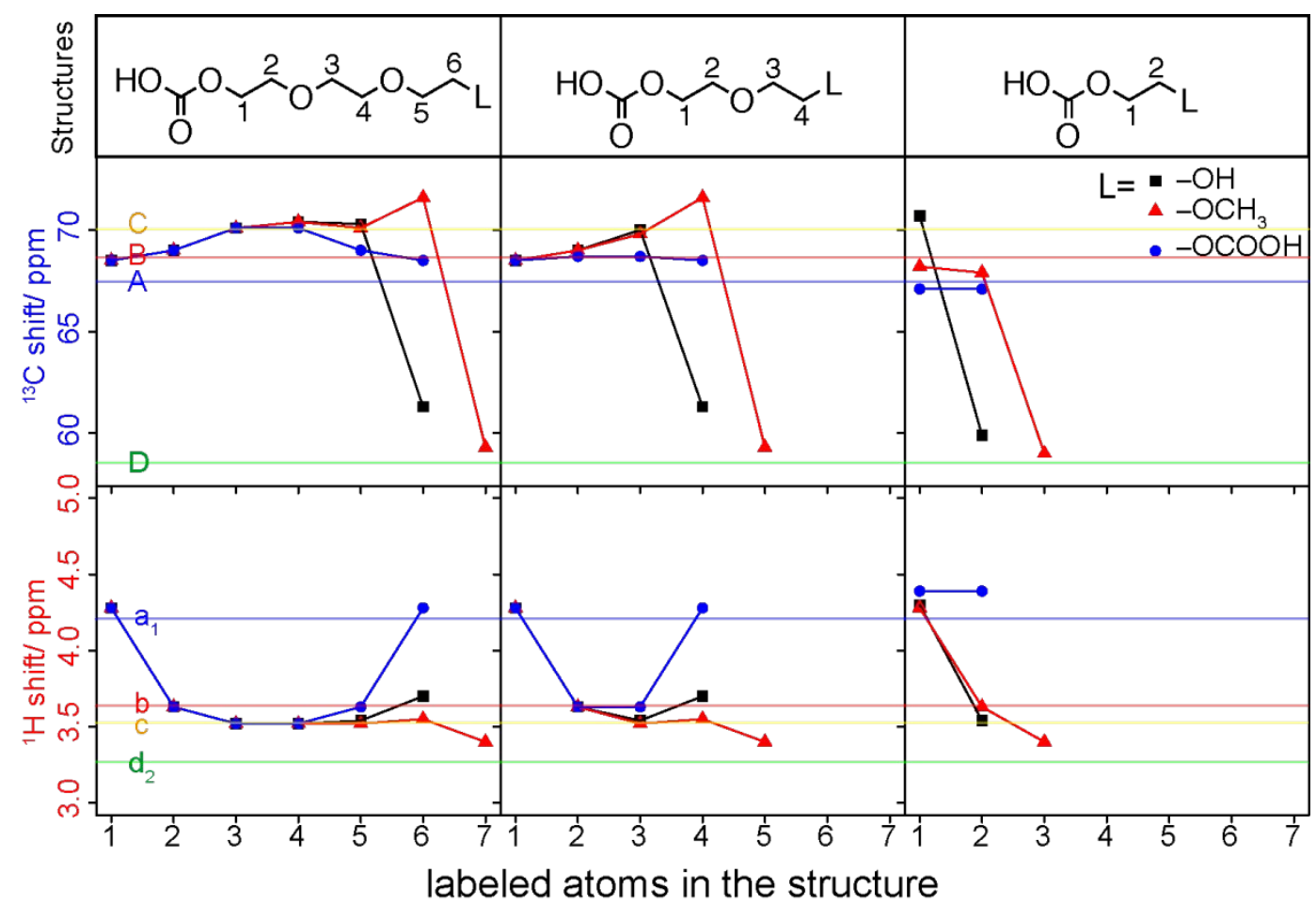

Figure S4. ${ }^{13} \mathrm{C}$ and ${ }^{1} \mathrm{H}$ NMR shift predicted by ChemDraw Software for alkyl carbonate oligomers with different end groups (hydroxide in black square, methoxide in red triangle, carbonate in blue dot) and different chain lengths (increasing ethylene oxide units from left to right). The atoms connected to the carbonate are labelled from 1 onwards. The experimental ${ }^{13} \mathrm{C}$ and ${ }^{1} \mathrm{H}$ NMR shifts values are drawn as solid lines with labels corresponding to the peaks observed in ${ }^{13} \mathrm{C}$ and ${ }^{1} \mathrm{H}$ NMR spectra. For oligomers containing methoxide ending group, the ${ }^{1} \mathrm{H}$ and ${ }^{13} \mathrm{C}$ $N M R$ is also predicted for the methoxide, and they are labelled as the last number.

A systematic investigation was made of oligomers with different end groups and varying chain lengths (HOCO$\left.\left(\mathrm{OCH}_{2} \mathrm{CH}_{2}\right)_{n}-\mathrm{R}, \mathrm{R}=-\mathrm{OH},-\mathrm{OCH}_{3},-\mathrm{OCOOH}, \mathrm{n}=1-3\right)$ in order to better understand the trend of the ${ }^{1} \mathrm{H}$ and ${ }^{13} \mathrm{C}$ shifts for these species. Figure S4 summarizes the chemical shifts within these oligomers. A general trend is that the ethoxy carbon near a carbonate group has a lower ${ }^{13} \mathrm{C}$ shift $(\sim 67 \mathrm{ppm})$ than carbons in the PEO chains $(\sim 70$ $\mathrm{ppm}$ ). The ethoxy carbon near a carbonate is labelled as site 1 (the middle panel in Figure S4), the chemical shift of which is always smaller than the ${ }^{13} \mathrm{C}$ shifts at sites 2 and 3 . The lower ${ }^{13} \mathrm{C}$ shift is due to the electron withdrawing nature of the carbonate group. On the other hand, the ethoxy carbon bound to the electron donating methoxide group $\left(\mathrm{R}^{\mathrm{C}} \mathrm{H}_{2}-\mathrm{OCH}_{3}\right)$ has a higher ${ }^{13} \mathrm{C}$ shift ( 72 ppm) than PEO carbon.

Experimental ${ }^{1} \mathrm{H}$ and ${ }^{13} \mathrm{C}$ shifts observed in the cycled electrolyte are shown as coloured lines in Figure $\mathrm{S} 4$, and the same labelling scheme is used here as it is in Error! Reference source not found.. Comparing the calculated values and the experimental results, proton $\mathbf{d}_{\mathbf{2}}$ can be safely assigned to a terminal methoxide group. The decrease of ${ }^{1} \mathrm{H}$ shift values from $\mathbf{a}_{1}$ to $\mathbf{b}$ and $\mathbf{c}$ can be explained by their distance to the next carbonate group. The structure derived from the calculation trend is consistent with the $2 \mathrm{D} \mathrm{NMR}$ experimental data, further confirming that $\mathrm{a}_{1}$ is part of a $\mathrm{ROCOOC} \underline{H}_{2} \mathrm{CH}_{2} \mathrm{R}$ fragment. 


\section{Mass spectroscopy}

Table S1. Mass spectroscopy data and the proposed structures with their corresponding mass.

\begin{tabular}{|c|c|c|c|c|c|c|}
\hline Structures & Samples & $\mathrm{n}$ & Formula & $\mathrm{m} / \mathrm{z}$ & $\begin{array}{l}\text { Experimental } \\
\mathrm{m} / \mathrm{z}\end{array}$ & $\begin{array}{l}\text { Calculated } \\
\mathrm{m} / \mathrm{z}\end{array}$ \\
\hline \multirow[b]{4}{*}{ Series $1_{n}$} & \multirow{3}{*}{ LP30 } & 4 & $\mathrm{C}_{11} \mathrm{H}_{20} \mathrm{O}_{8}\left\{\mathrm{CH}_{3} \mathrm{CN}\right\} \mathrm{Li}^{+}$ & 328 & 328.1607 & 328.1584 \\
\hline & & 5 & $\mathrm{C}_{13} \mathrm{H}_{24} \mathrm{O}_{9}\left\{\mathrm{CH}_{3} \mathrm{CN}\right\} \mathrm{Li}^{+}$ & 372 & 372.1866 & 372.1846 \\
\hline & & 6 & $\mathrm{C}_{15} \mathrm{H}_{28} \mathrm{O}_{10}\left\{\mathrm{CH}_{3} \mathrm{CN}\right\} \mathrm{Li}^{+}$ & 416 & 416.2144 & 416.2108 \\
\hline & \multirow{9}{*}{$\begin{array}{l}\mathrm{LP} 30+ \\
{ }^{13} \mathrm{C}_{3} \mathrm{EC}\end{array}$} & \multirow{3}{*}{4} & $\mathrm{C}_{11} \mathrm{H}_{20} \mathrm{O}_{8}\left\{\mathrm{CH}_{3} \mathrm{CN}\right\} \mathrm{Li}^{+}$ & 328 & 328.1606 & 328.1584 \\
\hline \multirow{8}{*}{$\mathrm{Li}^{+} \mathrm{CH}_{3} \mathrm{CN}$} & & & $\begin{array}{l}\mathrm{C}_{11} \mathrm{H}_{20} \mathrm{O}_{8}\left\{\mathrm{CH}_{3} \mathrm{CN}\right\} \mathrm{Li}^{+} \text {with } \\
\text { two }{ }^{13} \mathrm{C}\end{array}$ & 330 & 330.1672 & 330.1651 \\
\hline & & & $\begin{array}{l}\mathrm{C}_{11} \mathrm{H}_{20} \mathrm{O}_{8}\left\{\mathrm{CH}_{3} \mathrm{CN}\right\} \mathrm{Li}^{+} \text {with } \\
\text { four }{ }^{13} \mathrm{C}\end{array}$ & 332 & 332.1738 & 332.1718 \\
\hline & & \multirow{3}{*}{5} & $\mathrm{C}_{13} \mathrm{H}_{24} \mathrm{O}_{9}\left\{\mathrm{CH}_{3} \mathrm{CN}\right\} \mathrm{Li}^{+}$ & 372 & 372.1868 & 372.1846 \\
\hline & & & $\begin{array}{l}\mathrm{C}_{13} \mathrm{H}_{24} \mathrm{O}_{9}\left\{\mathrm{CH}_{3} \mathrm{CN}\right\} \mathrm{Li}^{+} \text {with } \\
\text { two }{ }^{13} \mathrm{C}\end{array}$ & 374 & 374.1933 & 374.1913 \\
\hline & & & $\begin{array}{l}\mathrm{C}_{13} \mathrm{H}_{24} \mathrm{O}_{9}\left\{\mathrm{CH}_{3} \mathrm{CN}\right\} \mathrm{Li}^{+} \text {with } \\
\text { four }{ }^{13} \mathrm{C}\end{array}$ & 376 & 376.1996 & 376.1980 \\
\hline & & \multirow{3}{*}{6} & $\mathrm{C}_{15} \mathrm{H}_{28} \mathrm{O}_{10}\left\{\mathrm{CH}_{3} \mathrm{CN}\right\} \mathrm{Li}^{+}$ & 416 & 416.2120 & 416.2108 \\
\hline & & & $\begin{array}{l}\mathrm{C}_{15} \mathrm{H}_{28} \mathrm{O}_{10}\left\{\mathrm{CH}_{3} \mathrm{CN}\right\} \mathrm{Li}^{+} \text {with } \\
\text { two }{ }^{13} \mathrm{C}\end{array}$ & 418 & 418.2187 & 418.2175 \\
\hline & & & $\begin{array}{l}\mathrm{C}_{15} \mathrm{H}_{28} \mathrm{O}_{10}\left\{\mathrm{CH}_{3} \mathrm{CN}\right\} \mathrm{Li}^{+} \text {with } \\
\text { four }{ }^{13} \mathrm{C}\end{array}$ & 420 & 420.2256 & 420.2242 \\
\hline \multirow{7}{*}{ Series $2 \mathrm{n}$} & \multirow{3}{*}{ LP30 } & 4 & $\mathrm{C}_{10} \mathrm{H}_{18} \mathrm{O}_{8} \mathrm{Na}^{+}$ & 289 & 289.0901 & 289.0899 \\
\hline & & 5 & $\mathrm{C}_{12} \mathrm{H}_{22} \mathrm{O}_{9} \mathrm{Na}^{+}$ & 333 & 333.1159 & 333.1162 \\
\hline & & 6 & $\mathrm{C}_{14} \mathrm{H}_{26} \mathrm{O}_{10} \mathrm{Na}^{+}$ & 377 & 377.1419 & 377.1424 \\
\hline & & & & & & \\
\hline & \multirow{9}{*}{$\begin{array}{l}\mathrm{LP} 30+ \\
{ }^{13} \mathrm{C}_{3} \mathrm{EC}\end{array}$} & \multirow{3}{*}{4} & $\mathrm{C}_{10} \mathrm{H}_{18} \mathrm{O}_{8} \mathrm{Na}^{+}$ & 289 & 289.0902 & 289.0899 \\
\hline & & & $\mathrm{C}_{10} \mathrm{H}_{18} \mathrm{O}_{8} \mathrm{Na}^{+}$with two ${ }^{13} \mathrm{C}$ & 291 & 291.0962 & 291.0966 \\
\hline & & & $\mathrm{C}_{10} \mathrm{H}_{18} \mathrm{O}_{8} \mathrm{Na}^{+}$with four ${ }^{13} \mathrm{C}$ & 293 & 293.1008 & 293.1034 \\
\hline \multirow[t]{6}{*}{$\mathrm{Na}^{+}$} & & \multirow{3}{*}{5} & $\mathrm{C}_{12} \mathrm{H}_{22} \mathrm{O}_{9} \mathrm{Na}^{+}$ & 333 & 333.1163 & 333.1162 \\
\hline & & & $\mathrm{C}_{12} \mathrm{H}_{22} \mathrm{O}_{9} \mathrm{Na}^{+}$with two ${ }^{13} \mathrm{C}$ & 335 & 335.1226 & 335.1229 \\
\hline & & & $\mathrm{C}_{12} \mathrm{H}_{22} \mathrm{O}_{9} \mathrm{Na}^{+}$with four ${ }^{13} \mathrm{C}$ & 337 & 337.1291 & 337.1296 \\
\hline & & \multirow{3}{*}{6} & $\mathrm{C}_{14} \mathrm{H}_{26} \mathrm{O}_{10} \mathrm{Na}^{+}$ & 377 & 377.1440 & 377.1424 \\
\hline & & & $\mathrm{C}_{14} \mathrm{H}_{26} \mathrm{O}_{10} \mathrm{Na}^{+}$with two ${ }^{13} \mathrm{C}$ & 379 & 379.1486 & 379.1490 \\
\hline & & & $\mathrm{C}_{14} \mathrm{H}_{26} \mathrm{O}_{10} \mathrm{Na}^{+}$with four ${ }^{13} \mathrm{C}$ & 381 & 381.1550 & 381.1558 \\
\hline
\end{tabular}

\section{Discussion of the presence of sodium impurity in the MS data}

The presence of $\mathrm{Na}^{+}$and the absence of $\mathrm{Li}^{+}$in the HRMS data is attributed to the sample preparation procedures. Since the concentration of the polymer in the cycled electrolyte is unknown, the sample was diluted with 1:3 ratio for three times with by $\mathrm{CH}_{3} \mathrm{CN}$ before $\mathrm{HRMS}$ measurement to avoid possible damage on the instrument. The $\mathrm{Li}^{+}$ may be diluted below the detection limit during this procedure and $\mathrm{Na}^{+}$may be introduced during sample handling. Nevertheless, the presence of the ether-dicarbonate oligomers is reproducible and the result is consistent with a comprehensive study by Gachot et al., ${ }^{3}$ who reported the same series $1_{\mathrm{n}}$ of degradation products in the EC-based electrolyte after electrochemical cycling. 


\section{Word of cautious for MS data:}

The HRMS measurement was performed in air with water contamination as water is an inevitable component in the carrier phase for HRMS measurement. Therefore, the detected species listed in S1 only indirectly aided our interpretation of the observed NMR data but does not directly contain the structural information nor the relative abundance of the degradation product.

\section{Simulated NMR spectra of oligomers and ${ }^{1} \mathrm{H}$ integral}
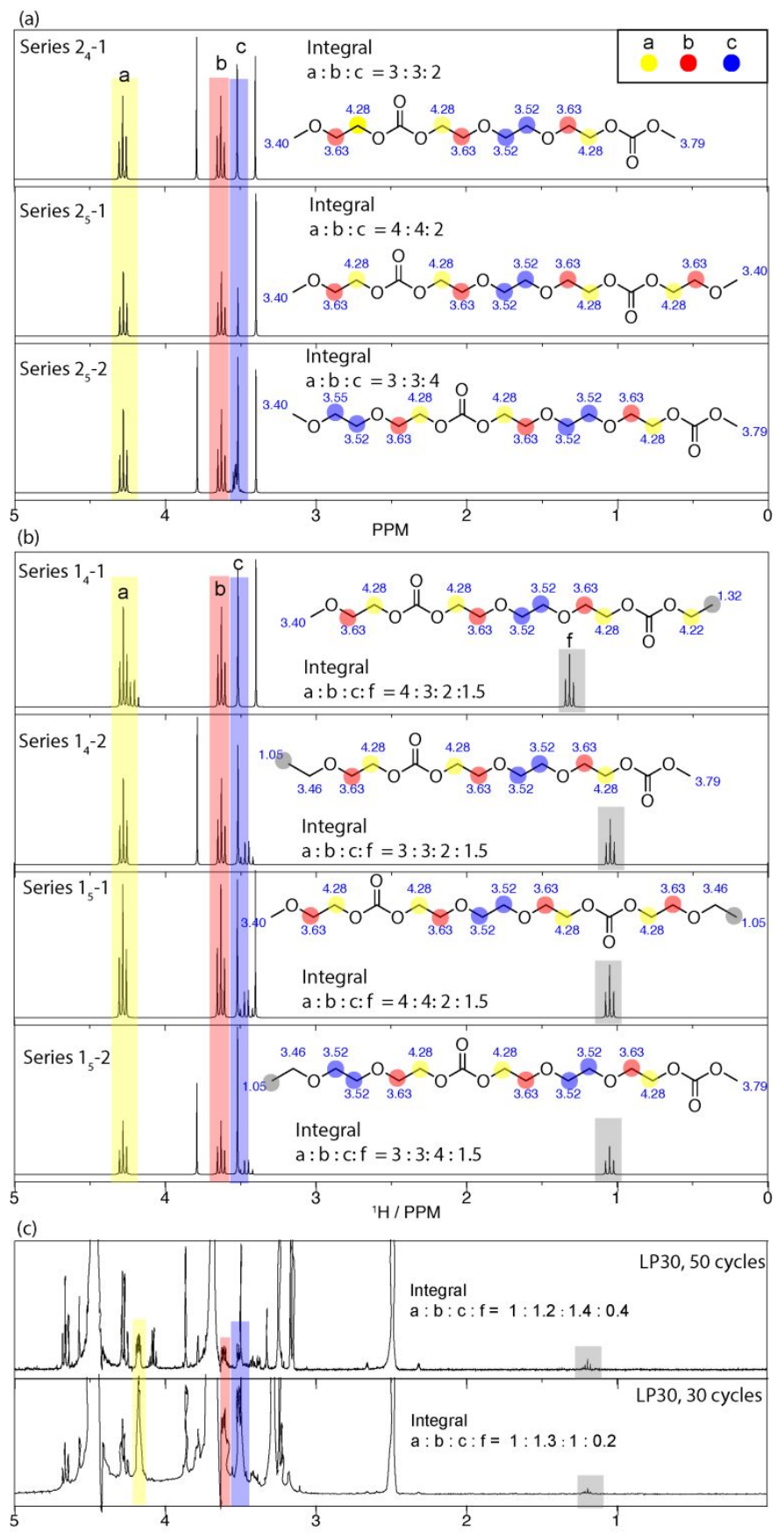

${ }^{1} \mathrm{H} / \mathrm{PPM}$

Figure S5. (a-b) Simulated ${ }^{1} H$ NMR spectra of oligomer series 1 and 2. Different protons are coloured in the structures and shaded in the ${ }^{1} \mathrm{H} N \mathrm{NR}$ spectra. Oligomers with different $\mathrm{EO}$ units in between the two carbonates groups lead to different integral ratio for proton a:b:c. (c) Experimental ${ }^{1} \mathrm{H} N M R$ spectra of the $L P 30$ samples after 30 and 50 cycles. 


\section{Reference:}

(1) Jin, Y.; Kneusels, N.-J. H.; Magusin, P. C. M. M.; Kim, G.; Castillo-Martinez, E.; Marbella, L. E.; Kerber, R. N.; Howe, D. J.; Paul, S.; Liu, T.; Grey, C. P. J. Am. Chem. Soc. 2017, 139 (42), 14992-15004.

(2) Wu, D. H.; Chen, A.; Johnson, C. S. Journal of Magnetic Resonance, Series A. 1995, pp 260-264.

(3) Gachot, G.; Grugeon, S.; Armand, M.; Pilard, S.; Guenot, P.; Tarascon, J. M.; Laruelle, S. J. Power Sources 2008, 178 (1), 409-421. 